\title{
EFFECT OF CERTAIN CULTURAL PRACTICES ON THE POPULATION DENSITY OF EPILACHNA CHRYSOMELINA F. (COLEOPTERA-COCCINELLIDAE) AT THE NEW VALLEY GOVERNORATE IN EGYPT
}

\author{
GAMEEL, S. M. M. AND BADR EL- SABAH A. FETOH
}

Plant Protection Research Institute, ARC, Dokki, Giza

(Manuscript received 9 August 2009)

\begin{abstract}
Field experiments were carried out to study the effect of three cucurbit crops, five planting dates and three levels of fertilization rates on the population densities of Epilachna chrysomelina F. (Coleoptera: Coccinellidae) during 2007and 2008seasons. The results indicated that, the two variables (cucurbit crops and planting dates) had pronounced effects on the numbers of $E$. chrysomelina on cucurbit plants. Regardless the effect of planting dates and fertilizer rates, sweet melon was more susceptible to the E. chrysomelina infestation than cantaloupe and watermelon harboring the highest population of the pest (75.95 and 105.73 individuals $/ \mathrm{m}^{2}$ ) during 2007and2008 seasons, respectively. Cucurbit plants cultivated in the late times (end of May and August) harbored relatively higher number of E. chrysomelina (larva and adults). Meanwhile, the plants of the early planting dates (end of March, middle of April and beginning of May) harbored relatively lower numbers of the pest.

Insignificant differences were found between the numbers of the pest on cucurbit crops under different levels of NPK rates during 2007 and 2008 seasons. In2007 season, the highest population densities of the pest were recorded on sweet melon plants (228.33, 152.67 and 143.00 individuals $/ \mathrm{m}^{2}$ ) during the fourth planting date (end of May) when the plants received double recommended, check and recommended dose of NPK, respectively. During 2008 season, unfertilized sweet melon plants recorded the maximum number of the pest (296.33 individuals $/ \mathrm{m}^{2}$ ) during the fourth planting date followed by cantaloupe plants (296.00 individuals $/ \mathrm{m}^{2}$ ) when cultivated during the fifth planting date and received double recommended dose of NPK.
\end{abstract}

\section{INTRODUCTION}

The melon ladybird beetle Epilachna chrysomelina F. (Coleoptera: Coccinellidae) is considered a serious pest of cucurbit plants in the New Valley (Bohlen and Freidel, 1979, Gameel, 2004, Gameel and Abdel-Gaid 2007 and Sayed and Gameel 2008 ) and is widely distributed in Egypt (Ghabn,1951, El-Saeady,1978, Ali and El-Saeady,1986 and Abdel-Moniem et al., 2004). Both larvae and adults cause great damage in a short 
time. Its feeding habits are phytophagous and injurious. It feeds on leaves, flowers and fruits of their host-plants, belonging mainly to the family cucurbitaceae. The damage to the leaves reduces the vegetative production of the host-plant, the result of which is a great loss in marketable crop yield. By feeding on the fruits, the beetles make large holes on which patches of rotten tissue appear later on. In case of heavy attack, the plants stop their growth, and even the whole plant may be entirely defoliate. Hence the quality and amount of yield are considerably reduced (Ghabn, 1951 El-Saeady,1978, Bohlen and Freidel, 1979 and Nazarov, 1988 ). The cultural practices such as cucurbit crops, planting seasons and fertilization rates play an important role in the change of the population density levels of pests attacking the plants. The growing of crop varieties which are less attacked than others or yield well in spite of attack is a very good pest control measure. Once such varieties are available, the control requires no extra labor and is therefore economical, moreover, the environment does not suffer from side-effects of the control measure (van Emden, 1977). As well as the planting date can be an effective pest management tactic because it results in a synchrony between the pests and crop (Albuquerque, 1993).

Little information were available in the literature concerning the effect of the cultural practices on the population density of $E$. chrysomelina and its importance. Therefore, the present study was conducted to evaluate the effect of certain cultural practices on the population density of the pest.

\section{MATERIALS AND METHODS}

Field experiments were conducted in the farm of the New Valley Experimental Station, El-Kharga, to study the effect of cucurbit crops, planting dates and fertilization rates on the population densities of E. chrysomelina during 2007 and 2008 seasons. The cultivated cucurbit cultivars were watermelon (Citrullus lantatus L.), Giza I, sweet melon (Cucumis melo var. aegytiacus L.), Balady and cantaloupe (Cucumis melo var. cantaloupensis L.) California. Each cultivar was planted in three replicates (each was $42 \mathrm{~m}^{2}$ ) during different five planting dates (end of March, middle of April, beginning and end of May and end of August).

Nitrogen was applied in the form of ammonium sulphate $(20.6 \% \mathrm{~N})$, phosphor was used in the form of calcium superphosphate $\left(15.5 \% \mathrm{P}_{2} \mathrm{O}_{5}\right)$ and potassium was added as potassium sulphate $\left(48 \% \mathrm{~K}_{2} \mathrm{O}\right)$. Nitrogen fertilizer was added in three equal doses during thinning, flowering and fruit setting stages of the plants while phosphor was only added during the thinning period and potassium was added in two periods, during thinning and flowering stages of the plants. Fertilization rates (Kg / Feddan) were, 1- Without Fertilization ( check), 2- Recommended rates of watermelon: ( $\mathrm{N}$ 
250, P 200, K 50 ) and sweet melon or cantaloupe (N 300, P150, K 100 ), 3Double recommended rates of watermelon (N 500, P 400, K 100 ) and sweet melon or cantaloupe (N 600, P 300, K 200). The conventional cultural practices were used and no chemical pesticides were applied during the present period. Simple square wooden wire $0.25 \mathrm{~m}^{2}(50 \times 50 \mathrm{~cm})$ was used as standard sample size. All stages of the pest (eggs, larvae, pupa and adults) were counted directly on the plants in a set of four square wires (one sample $=1 \mathrm{~m}^{2}$ ) (El-Saeady, 1978 and Gameel and Abdel-Gaid 2007). Samples were randomly taken weekly from each plot and continued from the vegetative stage up to the ripening stage of the plants. Data were statistically analyzed by F-test - and the means were compared according to Duncan's Multiple Range Test (Snedecor and Cochran 1971).

\section{RESULTS AND DISCUSSION}

\section{Effect of cucurbit crops}

Data in Table (1) show the average number of E. chrysomelina (larva and adults) recorded on three cucurbit crops (watermelon, sweet melon and cantaloupe) during 2007and 2008 seasons regardless the effect of planting dates and fertilization rates.

Table 1. Population density of Epilachna chrysomelina (adults and larva / m2) as affected by cucurbit crops.

\begin{tabular}{|c|c|c|}
\hline \multirow{2}{*}{ Cucurbit crops } & \multicolumn{2}{|c|}{ No. of individuals (adults and larva / $\mathrm{m}^{2}$ ) } \\
\cline { 2 - 3 } & 2007 & 2008 \\
\hline Watermelon & $25.93 \mathrm{~B}$ & $22.85 \mathrm{C}$ \\
Sweet melon & $75.95 \mathrm{~A}$ & $105.73 \mathrm{~A}$ \\
Cantaloupe & $20.06 \mathrm{~B}$ & $71.13 \mathrm{~B}$ \\
LSD (0.05) & 10.19 & 14.45 \\
\hline
\end{tabular}

Means followed by the same letter in each column are not significantly different at 0.05 level of probability.

There were significant differences between the number of the pest (larva and adults ) on the three cucurbit crops during the two studied seasons.

During season 2007, the highest population level of the pest (75.95 individuals / $\mathrm{m}^{2}$ ) was recorded on sweet melon plants and there no significant differences between the number of insects on watermelon and cantaloupe plants. Sweet melon plants harbored the highest number of the pest $\left(105.73\right.$ individuals $/ \mathrm{m}^{2}$ ) followed by 
cantaloupe (71.13 individuals $/ \mathrm{m}^{2}$ ) then watermelon (22.85 individuals / $\mathrm{m}^{2)}$ during season 2008.

The previous results revealed that (regardless the effect of both planting dates and fertilizer rates) sweet melon was more susceptible to the E. chrysomelina infestation harboring the highest population of the pest during 2007and2008 seasons. El-Saeady, 1978 found that, the generation period of E. chrysomelina was usually shorter in case of feeding on snake cucumber than feeding on other experimental hosts and Sayed and Gameel 2008 under the New Valley conditions found that, snake cucumber was more susceptible to the pest infestation harboring the highest population of the pest followed by cantaloupe. Meanwhile squash plants were the least susceptible one. This indicates the presence of some sort of resistance as recorded by Knipling (1979) Shukla and Upadhyay (1983) recorded that light had little influence on the attraction of the coccinellid to its host-plants, it was thought that chemical stimuli were involved. Meanwhile, Wilson( 1986) found that the development of the first instar larvae of $E$. cucurbitae Richards was delayed by the leaf hairs on pumpkin leaves, which prevented them from reaching the leaf surface to feed.

\section{Effect of planting dates}

Data in Table (2) showed that the effect of planting dates on the population density of the pest during the two successive seasons of 2007 and 2008 regardless the effect of cucurbit crops and fertilization rates. There were significant differences between the numbers of the pest on the plants throughout the different planting dates of 2007 and 2008 seasons.

Table 2. Population density of Epilachna chrysomelina (adults and larvae $/ \mathrm{m}^{2}$ ) as affected by planting dates, New Valley.

\begin{tabular}{|l|c|c|}
\hline \multirow{2}{*}{\multicolumn{1}{c|}{ Planting dates }} & \multicolumn{2}{|c|}{ No. of individuals (adults and larva / $\mathrm{m}^{2}$ ) } \\
\cline { 2 - 3 } & 2007 & 2008 \\
\hline 1st ( end of March) & $22.85 \mathrm{BC}$ & $0.15 \mathrm{C}$ \\
2nd (middle of April) & $9.22 \mathrm{C}$ & $2.59 \mathrm{C}$ \\
3rd (beginning of May) & $36.59 \mathrm{~B}$ & $11.70 \mathrm{C}$ \\
4th (end of May ) & $72.40 \mathrm{~A}$ & $104.40 \mathrm{~B}$ \\
5th ( end of August ) & $62.18 \mathrm{~A}$ & $178.00 \mathrm{~A}$ \\
LSD (0.05) & 14.39 & 30.20 \\
\hline
\end{tabular}

Means followed by the same letter in each column are not significantly different at 0.05 level of probability. 
The obtained data showed that, during 2007 season, the plants of the fourth and fifth planting dates showed relatively higher infestation levels compared to the plants of the other three planting dates recording 72.40 and 62.18 individuals $/ \mathrm{m}^{2}$, respectively.

Nearly the same trend of results was observed during season 2008 where the plants of the fifth and fourth planting dates showed relatively higher infestation levels compared to the plants of the other three planting dates recording $178 . .00$ and 104.20 individuals $/ \mathrm{m}^{2}$, respectively. Insignificant difference, however, was found between the numbers of $E$. chrysomelina recorded on the plants of first, second and third planting dates.

Regardless the effect of cucurbit crops and fertilizer rates, it could be observed that, the cucurbit plants cultivated in the late planting date harbored relatively higher number of E. chrysomelina (larvae and adults). Meanwhile, the plants of the early planting dates (March and April) harbored relatively lower numbers of the pest. ElSaeady 1978 found that, the greatest numbers of $E$. chrysomelina were recorded at July, September and November. Sayed and Gameel 2008 under the New Valley conditions found that, the cucurbit plants cultivated in the Nili plantation harbored higher numbers of $E$. chrysomelina than summer plantation. Variations of seasonal plantation can control pests, most of which show some seasonal frequency, either by crop avoiding the egg-laying period of the pest or by allowing the plants to have aged to resistant stage by the time the pest appears (van Emden, 1977). The time of planting season can be an effective pest management tactic because it results in a synchrony between the pests and crop (Albuquerque, 1993).

\section{Effects of fertilization rates}

Data in Table (3) show the effect of different levels of NPK regardless to the effect of cucurbit crops and planting dates on the population density of $E$. chrysomelinaduring2007and2008seasons.

Table 3. Population density of Epilachna chrysomelina (adults and larvae / m2) as affected by fertilization rates, New Valley.

\begin{tabular}{|l|c|c|}
\hline \multirow{2}{*}{ Fertilization rates } & \multicolumn{2}{c|}{ No. of individuals (adults and larva / $\mathrm{m}^{2}$ ) } \\
\cline { 2 - 3 } & 2007 & 2008 \\
\hline Check & $29.55 \mathrm{~B}$ & $54.69 \mathrm{~A}$ \\
Recommended & $44.06 \mathrm{~A}$ & $74.62 \mathrm{~A}$ \\
Double recon. & $48.33 \mathrm{~A}$ & $70.40 \mathrm{~A}$ \\
LSD. 0.05 & 14.24 & 20.97 \\
\hline
\end{tabular}

Means followed by the same letter in each column are not significantly different at 0.05 level of probability. 
In season 2007, the highest numbers of the pest (48.33 and 44.06 individuals / $\mathrm{m}^{2}$ ) were recorded on cucurbit plants received the double and recommended fertilization rates. The lowest number of E. chrysomelina (larva and adults) (29.55 individuals $/ \mathrm{m}^{2}$ ) was recorded on the check plants. During season 2008, insignificant differences were found between the numbers of the pest on cucurbit crops under different levels of NPK. Generally, it could be observed that, the infestation rates with E. chrysomelina do not affected by the fertilization rates.

\section{The interaction effects between cucurbit crops, planting dates and fertilization rates}

Data in Tables 4 and 5 show the effect of the three variables on the population density of E. chrysomelina during seasons 2007and 2008. Data in Table (4) indicate that, the highest population densities of the pest were recorded on sweet melon plants (228.33,152.67and143.00 individuals $/ \mathrm{m}^{2}$ ) during the fourth planting date (end of May) when the plants received double recommended, check and recommended dose of NPK, respectively. Followed by the cultivated plants during the third and fifth planting dates when received recommended and double recommended dose of NPK where they recorded (111.00and 109.33 individuals $\left./ \mathrm{m}^{2}\right)$, respectively.

Table 4. Population density of Epilachna chrysomelina (adults and larvae $/ \mathrm{m}^{2}$ ) as affected by cucurbit crops, planting dates and fertilization rates, 2007 season, New Valley.

\begin{tabular}{|c|c|c|c|c|c|c|c|c|c|c|}
\hline \multirow{4}{*}{$\begin{array}{l}\text { Planting } \\
\text { dates }\end{array}$} & \multicolumn{9}{|c|}{ No. of individuals (nymphs and adults $/ \mathrm{m}^{2}$ ) } & \multirow{4}{*}{ Average } \\
\hline & \multicolumn{3}{|c|}{ Water melon Cantaloupe } & \multicolumn{3}{|c|}{ Sweet melon } & \multicolumn{3}{|c|}{ Cantaloupe } & \\
\hline & \multicolumn{3}{|c|}{ Fertilization rates } & \multicolumn{3}{|c|}{ Fertilization rates } & \multicolumn{3}{|c|}{ Fertilization rates } & \\
\hline & Check & Recom. & Double & Check & Recom. & Double & Check & Recom. & Double & \\
\hline First & $19 . r \mathrm{r}$ & rt.tr & $9.7 \mathrm{~V}$ & $11 .$. & d. & ro.ru & Tr.t & $0 .$. & r. & rT.AO \\
\hline Second & $0 . r 4$ & T.r & V.rt & $0 . r+4$ & r^... & $1 \ldots$ & $1 \cdot .7 \mathrm{~V}$ & $\cdots$ & $19 .$. & Q.r \\
\hline Third & 1.r & $r+. .$. & ri.7V & rt... & $111 \ldots$ & ג.rr & YA.TV & rד.rT & $0 . .$. & $r 7.09$ \\
\hline Fourth & $\leqslant 7.7 \mathrm{~V}$ & ro.ru & TY.TV & 10r.7V & $1 \leqslant r . .$. & rYA.rT & IV.rT & r & $0 . r T$ & VT.E. \\
\hline Fifth & rr... & rq.7V & 10.rT & $\leqslant \wedge .$. & $97.7 \mathrm{~V}$ & 1.9.r & TY.TV & or.tV & RTtre & Ar.11 \\
\hline \multirow{2}{*}{ Average } & $r \cdot .9 r$ & rO.rT & TI.rT & ะq.Y. & ^৭.^. & 11.77 & 11.04 & $17 . \wedge \mathrm{V}$ & $r \leq . V q$ & \multirow{2}{*}{$\varepsilon . .70$} \\
\hline & \multicolumn{3}{|c|}{ ro.9r } & \multicolumn{3}{|c|}{10.90} & \multicolumn{3}{|c|}{$r \ldots r$} & \\
\hline
\end{tabular}

$\operatorname{LSD}(0.05)=55.16$ 
The lowest numbers of the pest were recorded on cantaloupe plants (5.00, 0.00 and 0.33 individuals $/ \mathrm{m}^{2}$ ) of the first, second and fourth planting dates when the plants received the recommended dose of NPK, respectively. Also, low numbers of $E$. chrysomelina (1.00 and 1.33 individuals $/ \mathrm{m}^{2}$ ) were observed on sweet melon and watermelon plants when cultivated during the second and third planting dates and received double recommended and check dose of NPK, respectively.

During season 2008, data in Table (5) clearly indicate that, the highest numbers of the pest were observed on sweet melon and cantaloupe plants cultivated during the late planting dates (end of May and August) under different levels of NPK. Unfertilized sweet melon plants recorded the maximum number of the pest (296.33 individuals $/ \mathrm{m}^{2}$ ) during the fourth planting date followed by cantaloupe plants ( 296.00 individuals $/ \mathrm{m}^{2}$ ) when cultivated during the fifth planting date and received double recommended dose of NPK.

Table 5. Population density of. Epilachna chrysomelina (adults and larvae $/ \mathrm{m}^{2}$ ) as affected by cucurbit crops, planting dates and fertilization rates, season 2008.

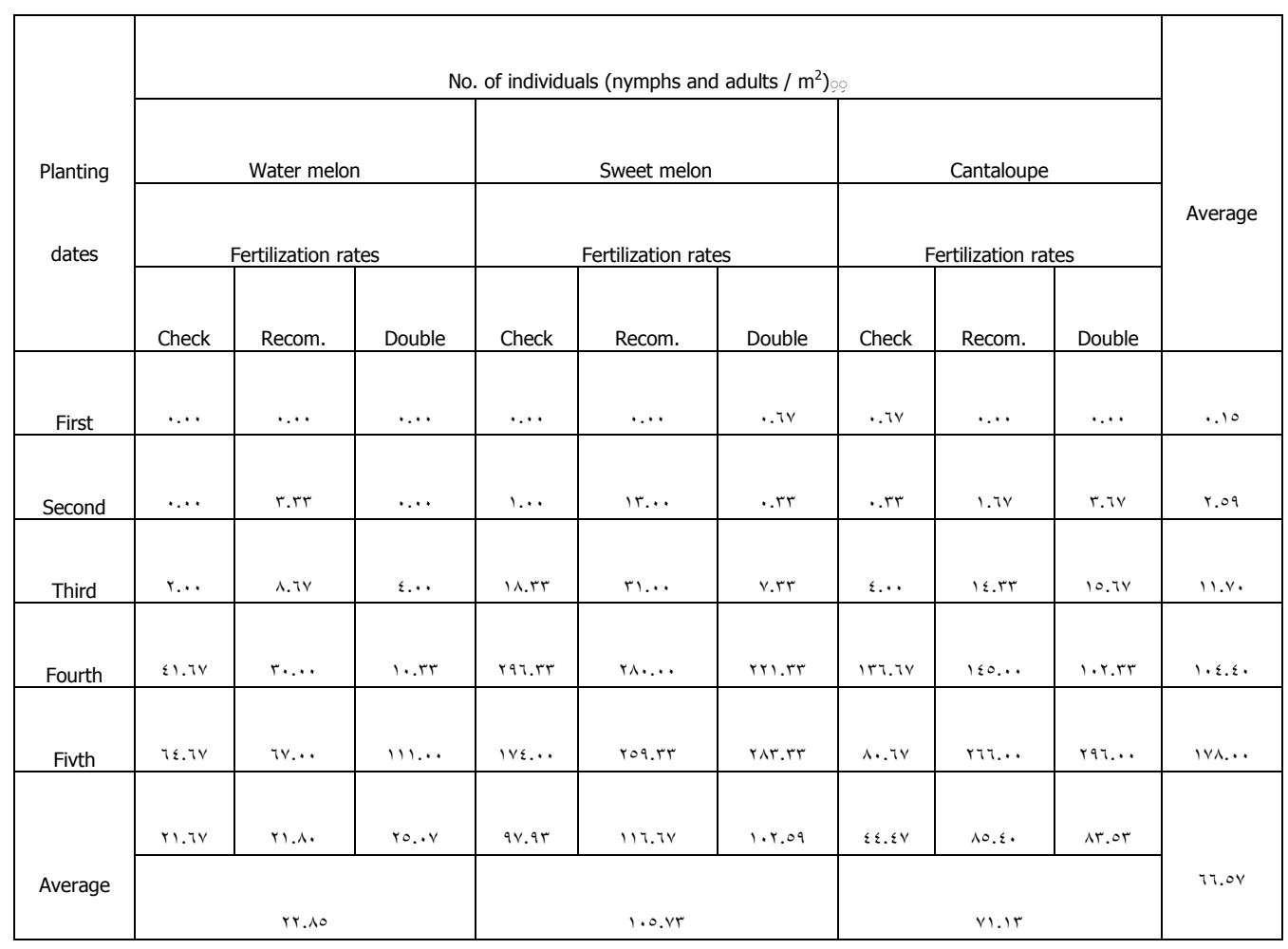

$\operatorname{LSD}(0.05)=81.22$

The lowest numbers of $E$. chrysomelina which ranged between 0.00 and 31.00 individuals $/ \mathrm{m}^{2}$ were recorded on watermelon sweet melon and cantaloupe plants in early planting dates (end of March, middle of April and beginning of May) under different levels of NPK. 
From the data of 2007 and 2008 seasons it is clear that, sweet melon was more susceptible to $E$. chrysomelina infestation harboring the highest population of the pest. Cantaloupe crop was moderately susceptible to the pest infestation, whereas watermelon was the least susceptible cucurbit crop. Lower population density of the pest was recorded on the plants of the early planting dates. In conclusion, to reduce the damage caused by the E. chrysomelina on the cucurbit plantations in the New Valley it could by recommend to cultivate the cucurbit crops in the early planting dates.

\section{REFERENCES}

1. Abdel-Moniem, A. S. H., A. A. Gomaa, N. Z. Dimetry, T. Wetzel and C. Volkmar. 2004. Laboratory evaluation of certain compounds against the melon ladybird, Epilachna chrysomelina F.attacking cucurbit plants. Archives of Phytopathology and Plant Protection. 37:71-81.

2. Albuquerque, G. S . 1993. Planting time as a tactic to manage the small rice stink bug, Oebalus poecilus (Hemiptera:Pentatomidae) in Rio Grande do Sul, Brazil. Crop Protection, 12:627: 630.

3. Ali, M. A. and A. A. El-Saeady. 1986. Phenology and population dynamics of the melon ladybird beetle Epilachna chrysomelina (F) in Egypt (Coleoptera:Coccinellidae). Agric. Res. Rev. 61:179-191.

4. Bohlen, E. and J. W. Freidel. 1979. Crash Programme - Plant Protection New Valley, Egypt. Consultancy Mission. 14.02.1979 7.03.1979. German Agency for Technical Cooperation (GTZ), 56 pp.

5. El-Saeady, A. A. 1978. Ecological and physiological studies on melon ladybird beetle Epilacha chrysomelina(F.), ( Coleoptera-Coccinellidae ). Ph. D. Thesis, Fac. of Agric., Al-Azher Univ., 146 pp.

6. Gameel, S. M. M. 2004. Eco-Biological studies on the black melon bug, Coridius (Aspongopus) viduatus F. ( Hemiptera : Pentatomidae ) in the New Valley . Ph. D. Thesis, Fac. of Agric., Assiut Univ., 209 pp

7. Gameel, S. M. M. and Abdel-Gaid. 2007. Relative susceptibility of three cucurbit vegetables to the infestation Epilachna chrysomelina F. (Coleoptera-Coccinellidae) at the New Valley - Egypt. The $1^{\text {st }}$ International Conference on Desert Cultivation.27-29March, Minia Univ.85-90. 
8. Ghabn, A. A. E. 1951. Studies on the biology and control of Epilachna chrysomelina F., in Egypt ( Coleoptera - Coccinellidae ). Bull. Soc. ent. Egypte. 35:77-108.

9. Knipling, E. F. 1979. The basic principles of insect population suppression and management. USDA Agric. Agriculture- Handbook. 512pp.

10. Nazarov, D. T. 1988. Tests with preparations. Zashchita Rastenii Moskva, 11:31.

11. Sayed, A. A. and S. M. M. Gameel. 2008. Effect of some vegetable cucurbit crops and seasonal plantation on the population densities of Epilachna chrysomelina $\mathrm{f}$. (Coleoptera-Coccinellidae), at the New Valley-Egypt. Egyptian J. Agric. Res.86(3):1053-060.

12. Shukla, G. S. and V. B. Upadhyay. 1983. Effect of ecological factors: food preference of Epilachna dodecastigma (Coleoptera: Coccinellidae) on vegetable plants. (i) Light. Journal of Advanced Zoology. 1983, 4(1): 49-54.

13. Snedecor, G. W. and W. G. Cochran. 1971. Statistical methods. Iowa state Univ. Press, Ames, Iowa. USA.

14. Van Emden, H. F. 1977. Pest control and its ecology. Edward Arnold (Publishers) Ltd, London. $59 \mathrm{pp}$.

15. Wilson, L. J. 1986. Movement and feeding patterns of Epilachna cucurbitae Richards (Coleoptera : Coccinellidae ) on pumpkin and zucchini plants. Australian Journal of Ecology. 11(1): 55-62. 


\section{تأثير بعض العمليات الزراعية على الكثافة العددية لحشرة خنفساء القثاء بمحافظة}

\section{الوادي الجديد في مصر}

$$
\text { معهد بحوث وقاية النباتات - مركز البحوث الزراعية - الدقي - الجيزة محمود محمد الصباح عبد المنعم فتوح }
$$

أجريت هذه الدراسة بمزرعة محطة البحوث الزراعية بالخارجة - الوادي الجديد لمعرفة تأثنير

كل من بعض المحاصيل القرعية ومواعيد الزراعة وكذلك معدلات التسميد على الكثافة العددية لحشرة

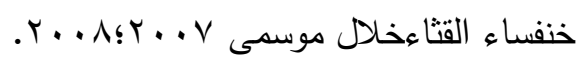
اوضـت النتاتج ان عاملى المحصول القرعى المنزرع وميعاد الزراعه هـا العاملان المحددان لدرجـه الاصابه بحشرة خنفساء القتاء. ا

أوضحت النتائج وجود اختلاف معنوي في تعداد هذه الافة على كل من محصول الثمام

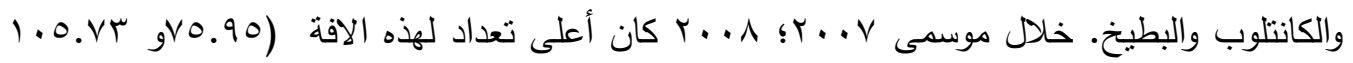

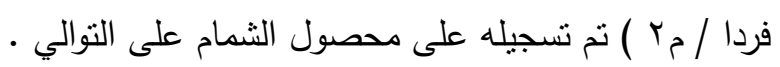
: - تأثيرعروات الزراعة

سجلت المحاصيل القرعية المنزرعة فى مواعيد زراعه متأخره (نهايه مايو و نهايه اغسطس)أعلى تعداد لهذه الآفه بينما اقل تعداد لهذه الآفه سجل فى مواعيد الزراعه المبكره(نهايه مارس و منتصف ابريل وبدايه مايو.

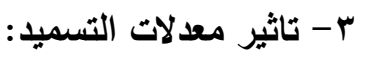
من خلال النتائج لم تظهر الاختلافات فى معدلات التسميد اى تأثنر فى تعداد حشرة خنفساء

$$
\text { القتاء خلال موسمى الدراسه. }
$$

؟ - التأثير المشترك لكل من المحاصيل القرعية و عروات الزراعة و معدلات التسميد على تعداد

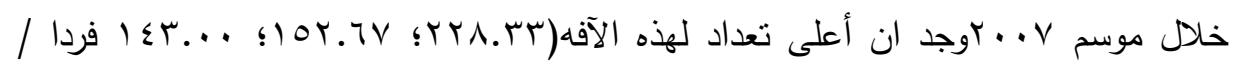
مrY) تم تسجيله علنباتات محصول الثمام المنزرعه فى نهايه مايو و التى تلقت مستوى مضاعف من

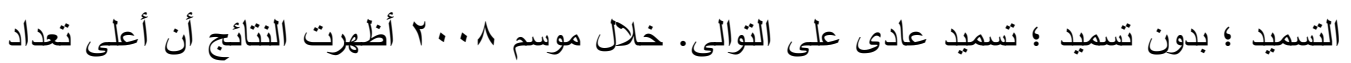

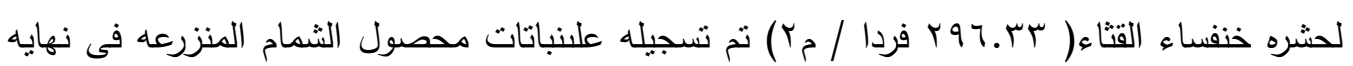

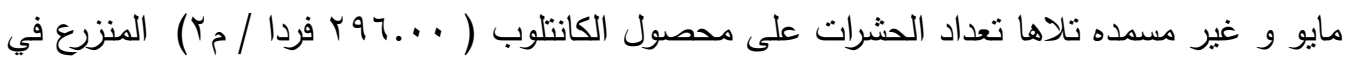
نهايه اغسطس و الذى تلقى مستوى مضاعف من التسميد. 